\title{
Article
}

\section{Towards practice-based studies of HRM: an actor-network and communities of practice informed approach}

\author{
Vickers, David and Fox, Stephen \\ Available at http://clok.uclan.ac.uk/5217/ \\ Vickers, David ORCID: 0000-0002-7220-8789 and Fox, Stephen (2010) \\ Towards practice-based studies of HRM: an actor-network and communities of \\ practice informed approach. The International Journal of Human Resource \\ Management, 21 (6). pp. 899-914. ISSN 0958-5192
}

It is advisable to refer to the publisher's version if you intend to cite from the work. http://dx.doi.org/10.1080/09585191003729366

For more information about UCLan's research in this area go to http://www.uclan.ac.uk/researchgroups/ and search for <name of research Group>.

For information about Research generally at UCLan please go to http://www.uclan.ac.uk/research/

All outputs in CLoK are protected by Intellectual Property Rights law, including Copyright law. Copyright, IPR and Moral Rights for the works on this site are retained by the individual authors and/or other copyright owners. Terms and conditions for use of this material are defined in the policies page.

\section{CLoK}

Central Lancashire online Knowledge www.clok.uclan.ac.uk

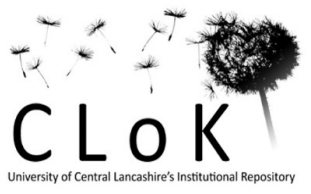




\title{
Towards practice-based studies of HRM: An Actor-Network and Communities of Practice informed approach
}

\author{
David Vickers and Stephen Fox \\ University of Central Lancashire, Preston, UK and Lancaster University, UK. \\ Correspondence: Dr. D. Vickers, Gr252, LBS, UCLAN, Preston, PR1 2HE.
}

(Received 30 September 2008; final version received 1October 2009)

\begin{abstract}
HRM may have become co-terminus with the new managerialism in the rhetorical orthodoxies of the HRM textbooks and other platforms for its professional claims. However, we have detailed case-study data showing that HR practices can be much more complicated, nuanced and indeed resistive toward management within organizational settings.
\end{abstract}

Our study is based on ethnographic research, informed by actor-network theory and community of practice theory conducted by one of the authors over an eighteen month period. Using actor-network theory in a descriptive and critical way, we analyse practices of managerial resistance, enrolment and counter-enrolment through which an unofficial network of managers used a formal HRM practice to successfully counteract the official strategy of the firm, which was to close parts of a production site. As a consequence, this network of middle managers effectively changed top management strategy and did so through official HRM practices, coupled with other actor-network building processes, arguably for the ultimate benefit of the organization, though against the initial views of the top management.

The research reported here, may be characterised as a situated study of HRM-in-practice and we draw conclusions which problematize the concept of HRM in contemporary management literature.

Keywords: HRM, actor-network theory, ethnography, community of practice 


\section{Introduction}

This paper responds to the calls for more longitudinal qualitative case studies of HR practices in situ (Purcell 1999; Watson 2004). We know from the existing critical qualitative literature on HR, that HR practice is a highly political management process involving technically, morally, socially and emotionally complex,

calculations and sensitive assessments of the value of different human contributions to the overall value-chain of a firm (e.g. Keenoy 1999; Watson 1994). In contrast with approaches which downplay the socio-political aspect of HR, there are increasing calls that practitioners, other stakeholders and commentators should recognise and embrace the socio-political aspect of HR work, and that critical HR studies should seek to help to illuminate it. In management studies this 'turn to practice' is seen for example in communities of practice (Brown and Duguid 1991; 2001) social and organizational learning (Fox 2000, 2005, 2006). However, while the turn to practice has generally advocated ethnographic longitudinal studies of many different forms of work practice, this literature also draws upon a wide range of theoretical positions. These address the relationship between human or social practices and the material environment and technological devices through which many professional human practices engage with the social and material realities of the workplace (see Gherardi 2009 for an overview). The approach which has done most to articulate the conceptual issues in mixing humans and nonhumans together in such ways is actor-network theory (Law 1991; Law and Hassard 1999; Latour 2007), and it is this approach which we draw upon in the study reported below. This ANT approach enables us to demonstrate the power relations issues prevalent in HR practices.

The present paper, based on an eighteen month longitudinal ethnographic study of HRM-in-practice, examines HR work in the context of management activities in pursuit of a post-acquisition strategy. 
Actor-network theory (ANT) recognizes and provides a language for understanding and describing power in action. As Law (1992, p. 387) notes:

\footnotetext{
...actor-network theory is all about power - power as a (concealed or misrepresented) effect, rather than power as a set of causes. Here it is close to Foucault (1979), but it is not simply Foucauldian for, eschewing the synchronic, it tells empirical stories about processes of translation.
}

Some have argued ANT’s Foucauldian approach to power is relevant to the study of HRM and organizational power effects (Fox 1989, 2000; Townley 1993a, 1993b, 1998, Vickers and Fox 2005). This paper will tell an empirical story about processes of translation found in a study of HR management work, drawing on Fox (2000) who discusses ANT in relation to Foucault and Communities of Practice Theory (COPT). Specifically, ANT's concept of 'translation' enables us to answer the questions posed by Watson (2004, p. 447) who argues HRM should be explored in situ and studies should address: (i) how HR policies come into being, (ii) how strategy is shaped in practice, and (iii) what are the politics between managers? Using the ANT perspective, we focus particularly upon HR working practices but show how these are interwoven with other managers' practices as well. Part of the nature of HR work lies in its relationship with line management’s strategies and day-to-day activities, which is the cause of some of the organizational tensions and ambiguities with which HR work must engage. Here HR work is shown to involve micro-political negotiating which translates many different interests of competing groups of managers' (the politics between managers) into a single public course of action towards which most managers and other stakeholders could work (how strategy is shaped in practice). In the political process we describe here, an initial verbal agreement between managers and unions was based on a key HR text (redundancy procedure), the current relevance of which relied upon specific communities and 
networks of practice recollecting it and bringing it into play (how HR policies come into being).

We then recount the case of redundancy practices at a production plant (Burnsland) [pseudonyms are used throughout to allow wider use of the field notes] which was acquired by an American multinational company (Chemco) from a UK multinational (HCI) as part of a \$1 billion acquisition. Our ethnographic study allowed us to consider the linkages between HRM practices and the emergent strategy of the firm (compare: Mintzberg and Walters 1985; Whittington, 1996).

We argue for more situated studies of HR practice that show SHRM is infused with complex power relations and effects. Currently much of the SHRM literature is unitarist (Fox, 1974; Burrell and Morgan 1979) in nature and seeks to identify 'best practice' or 'best fit' between core practices. Theses studies appear to suggest that 'management' are all singing from the same hymn sheet whereas our study problematizes this view.

\section{Actor-Network Theory as a practice-based approach}

The study we report is of situated HR management work practices which were a response to the instructions of incoming (post-acquisition) senior managers to close production lines and make staff redundant. HR work practices embody forms of knowledge, and our study shows how HR practices and embodied knowledge emerge together and have power effects, in situated detail.

The idea of ethnographically studying socially situated practices goes back to Garfinkel's (1967) studies of practical action (Fox 2006) and ANT authors acknowledge a debt to Garfinkel (Latour 2007). There have been a number of 
developments in the study of work practices, since the 1960s. Out of these traditions came many ethnographic studies of situated workplace practices, which established COPT in the 1990s (Lave and Wenger 1991; Brown and Duguid 1991; Hutchins 1991; 1995; Orr 1990, 1996; Luff, Hindmarsh and Heath 2000),

ANT was part of this turn to practice and like ethnomethodology and the COPT; it drew upon ethnographic studies of action (e.g. Latour 1987) and crossed 'the resources of ethnomethodology ... with those of semiotics' (Latour 2007, p. 122). ANT analyses became distinctive for their approach to issues of power and knowledge, based on Foucault (Latour 1986; Law 1992) and the attention his accounts of power/knowledge give to micro-practices of inscription and their impact on the subject.

The idea of the social in ANT, was originally tied to the idea of social interests in the building of alliances to socially produce scientific proofs (Latour 1986). If this is true of scientific knowledge, probably it is even truer of management knowledge, where 'scientific method' has more limitations and enjoys less privilege. Although professional HRM work makes many sorts of pseudo-scientific claims (e.g. psychometrics, job-evaluations), its knowledge is also a social product in the actornetwork view. This, of course, does not make it useless. On the contrary, Latour's point is that social networks produce the usefulness of some facts and theories over others.

One central idea ANT contributes to our understanding of social products, from 'knowledge to agents, social institutions, machines, and organizations,' is that all of these 'may be seen as a product or an effect of a network of heterogeneous materials', for social products, social things, always come in 'material forms' (Law 
1992, p. 381). ANT treats the social (human) and material (nonhuman) as analytically equal [called symmetry in ANT; see for example Latour 1987] in its analyses of how networks grow and fall apart; which is not to say that it treats humans and nonhumans as equals in terms of ethics (Law 1992, p. 383).

Material forms are not simply pieces of equipment, or 'natural' material objects, but as Law explains are made into social things or products through practices and processes of 'heterogeneous engineering in which bits and pieces from the social, the technical, the conceptual, and the textual are fitted together, and so converted (or 'translated') into a set of equally heterogeneous scientific products' or indeed organisational products (Law 1992, p. 381).

Further, the processes and products of heterogeneous engineering are primarily ‘interactional effects’ (Law 1992, p. 389). Canonical studies of ANT examine interactional effects from various angles but one angle, especially relevant to this study, focuses on interactions that disguise the interests of the parties-ininteraction (Callon and Law 1982; Callon 1986; Law 1986). As Callon (1986) showed, betrayal and deceit is an aspect of certain interest-laden interactions and our study will show that betrayal and deceit was central to both the practice of general management, and HR management in particular, echoing previous ethnography-based studies of managers (Jackall 1988).

Our approach, draws specifically on a blend of ANT and COPT; although power relations tend to be more a feature of ANT than COPT (Fox 2000; Hughes, Jewson and Unwin 2007; Jewson 2007). ANT sees power not as a possession or object 'but as an attribute of the functioning of networks, not diffused from above or centrally’ (Hughes et al 2007, p. 7). 
CoPs are arguably a particular kind of actor-network, a kind in which ‘legitimate peripheral participation’ (Lave and Wenger 1991) converts (or 'translates') newcomers into old-timers, and people who know little into people who know a lot about that set of practices which a community of practice shares, through day-to-day actions that build mutual engagement, joint enterprise and shared repertoires (Wenger 1998). As Orr $(1990,1996)$ argues from his study of photocopier repair technicians, much of this work of conversion or translation is done through interactions amongst participants with the aid of storytelling.

Orr (1996) makes three general points about storytelling practices. First, ‘technician’s stories are work; they are part of diagnosis, and they help preserve the knowledge acquired for the benefit of the community’ (p.143). Second, drawing on Harvey Sacks, Orr (1996, p. 141) explains the stories the technicians told were the ones the community regarded as 'storyable, remarkable'; thus many of the known-incommon aspects of their work were routine to them (e.g. every service call is roughly the same) so 'stories that work well for members of a culture may seem remarkably cryptic and elliptical to outsiders' (p.141) because they focus only on details that are not routine and presume their routine world in common. Finally, 'technicians clearly tailor their stories to the occasion of their telling' (p.141), allowing them to add more detail when addressing outsiders for instance. In other words, storytelling is a situated practice, the reasons for telling stories always local and occasioned in situ.

Our study shows parallels to these three points: HR managers use story-telling with other managers to (i) diagnose their situation and decide how to act; (ii) speak a cryptic language and (iii) tailor their interactions with different audiences. 


\section{Methodology}

The methodology adopted was informed by ethnography. Hammersley and Atkinson (1983, p. 93) drawing on Junker's (1960, p. 36) fieldwork categorisation describe the complete participant and the participant as observer - both of which emphasise the comparative involvement of the researcher. The author who conducted the research had worked in Human Resources for 15 years, 10 of which were for HCI prior to conducting this research. He managed the processes related to the transfer of employees from HCI to Chemco. He then elected to transfer and relocated to Burnsland. As such he was a newcomer to both Chemco and Burnsland which allowed for some level of detachment. However, using Hammersley and Atkinson’s terms this particular HR manager was a researcher whose role mainly shifted between complete participant and participant observer.

The researcher is an actor (Andy Dalton - the HR manager) in this story. Hammersley and Atkinson observe that a researcher 'may play an important part in shaping the context' and that as an 'active participant ... he or she is the research instrument par excellence’ (1983, p.18). Andy Dalton’s primary function was being an active participant and observation was always secondary to his job role. As Alvesson (2003) suggests the observation role only becomes primary at a specific time when the detailed notes taken at the time are analysed and the writing process begins. The researcher negotiated access to study the managers-in-action within Burnsland after previously negotiating the same within HCI, through promising to use pseudonyms for all names. In writing field notes the author was able to use the common practice of Burnsland managers of writing down notes in their note books even if his notes were more copious than normal. Where this was not possible the author was able to write notes up every evening. During the eighteen months study he 
made of Burnsland management-in-action, naturally the focus for his attention was the work of HR management practices which included but were far more extensive than his own personal role, since HR practices were distributed across a shifting network of managers ranging from the incoming Chemco Site Manager, senior directors within Burnsland and elsewhere in Chemco (in Europe and the US) to various middle managers, trade union officials and others. Although he had an advisory role in regard to HR management practices, other managers were also responsible for HR management-in-action and there were other sources of HR advice in play apart from himself. However, his participant role definitely gave him wide ranging and legitimate access to the particular change process described here (the rollout of a redundancy programme) and many concomitant HR management practices.

As well as extensive field notes written documents were gathered ranging from letters, procedures, agreements, media reportage and internal records. These various ‘inscription devices’ played a part in the interactions amongst managers, helping to generate certain power-effects when mobilised by some against others for instance, in ways we shall illustrate below.

There are several areas of common ground between Alvesson’s (2003) ‘selfethnography', and the authors’. Firstly, the 'idea of self-ethnography is to utilize the position one is in... [for]... secondary purposes, i.e. doing research on the setting of which one is a part' (p. 175). This is neither to produce autobiography nor autoethnography (Ellis and Bochner, 2000), both of which place the writer's personal experiences at the centre of the analysis; rather the aim is to 'carry out cultural analysis and not introspection' (Alvesson, 2003, p.175). An alternative term could be 'home-culture-ethnography or insider ethnography' and the main difference from 
conventional ethnography is that the researcher's 'home-base ... is the setting being studied' (p.176), rather than some other site where the researcher is a stranger. This approach is ideal for practising managers who wish to conduct research projects as part of their masters or doctoral theses for instance, as it makes a virtue out of their intimate knowledge of the research site.

However, there are problems with self-ethnography which need to be overcome; largely that the researcher is no longer studying 'them' but 'us' and this requires him or her making the taken-for-granted, cryptic and familiar sufficiently strange as to become critically analyzable, storyable and remarkable. Thus in the study we report below, we frequently quote some cryptic utterances or action made by a manager in situ but then add some context which explains the background knowledge assumed. Alvesson (2003, pp.185-87) suggests several ways in which the researcher may be able to look at their familiar home-base with fresh eyes, three of which are used in the present study: (i) by taking naturally occurring breakdowns of participants' understandings within the site as opportunities to inspect their assumptions and expectations; (ii) by 'embracing positions of irony and self-irony .. in order to create a certain distance to more serious arguments put forward' (pp.1856); and (iii) 'the use of theories which challenges common sense' and here Foucault's work is expressly cited as it 'may help shake around fixed preunderstandings' (p.186).

In these terms, the researcher found that: (i) the acquisition and postacquisition process pitted the incoming Chemco management's view of Burnsland against the local (former HCI) management's view creating a natural breakdown of assumption and expectations; (ii) the former HCI managers readily ironised the viewpoints and manoeuvres of the incoming Chemco Site Manager, making visible to 
an insider internal differences about the nature of proper or improper HR management practices and; (iii) the use of ANT, informed by Foucault's understanding of power/knowledge, forced the researcher, as an insider, to reframe many daily activities within a non-intuitive set of conceptual categories, of which the symmetry between human and non-human actants, discussed above, was just one. In these ways the researcher, as he made his field notes, made his home-base as an HR management practitioner strange to himself and reportable in terms which describe and explain HR management work practices but view them through a filter of theoretical understandings of power and knowledge.

Our self-ethnographic approach below follows Alvesson, Hardy and Harley (2008, p.484) who describe the use of reflexivity as a positioning practice where reflection 'goes beyond a focus on authorial identity' in order to explore ‘the broader social landscape within which research and researchers are positioned'. This approach is designed to avoid privileging the author (Foucault, 1991, p. 101) and as such we deliberately describe the author-researcher in the third person. This is a common practice in ANT accounts including those that involve the author as participant (e.g. Moser and Law 1999) or are more personal in nature (Singleton and Michael 1993). This story has been told to several people who were present at Burnsland at that time to test its credibility and authenticity and it has not been changed as fellow participants recognise and understand the story in the same way.

\section{HRM and management practices at 'Burnsland'}

In this section, first we outline the main events in the story of change at Burnsland, a chemicals plant sold off by HCI to Chemco in a \$1 billion acquisition; and then, in 
some depth, we examine one specific HR practice - the implementation of a redundancy policy - shedding light on the questions we derived from Watson: (i) how HR policies come into being, (ii) how strategy is shaped in practice, and (iii) what are the politics between managers? This story follows actions-in-context at the site as observed by the HR manager utilizing the unique access he had to the development and shaping of events.

In brief, a long-established UK chemicals firm (HCI) sold Burnsland, a business unit to Chemco, a long established US chemicals firm along with a package of other European holdings, including a Dutch plant, for \$1bn and Chemco put in place a new site manager in charge of Burnsland. Then Chemco senior management in both the US and Europe decided to rationalise production - working out what production lines to shut down, what to keep, invest in and develop. They asked for figures from all production plants. The Dutch supplied their Chemco bosses with projections, whilst Burnsland supplied actual figures. Accordingly, the Burnsland plant was compared unfavourably to the Dutch plant by the post-acquisition process; unfairly in the view of Burnsland managers because the Dutch had no history of achieving such projections. However, as the Dutch projections were higher than Burnsland's actual figures, Chemco decided and announced it would close three production lines at Burnsland out of a possible nine, and to make 200 compulsory redundancies (80 of which within 90 days), and decided plans for two more to follow which it left unannounced.

The new site manager sought to manage this change as a planned process of closure and redundancy, but the local (former HCI) managers resisted. One of these managers was then sidelined and told he would be transferred, which shocked the others whose resistance to line closures then went underground. A number of 
managers then enrolled each other becoming a heterogeneous network of allies (human actors and actants (see Latour 1988), such as the text of an agreement, specific lists of redundancies) taking public charge of the closure and redundancy programme, through a regular meeting everyone called 'the engine room', which publicly sided with the site manager, while backstage it simultaneously set about slowing down the change programme seeking ways to derail it altogether. A longstanding HCI HR policy was recollected by the engine room managers and then used in intricate ways to slow the change down.

In what follows we will examine these intricate ways in more detail using actor-network concepts to help us understand the intricacies. By the end of the eighteen months we had access to, the outcomes were that: (i) only two out of three production lines announced for closure were closed on time according to Chemco's post-acquisition plan; (ii) a third ear-marked by Chemco for closure at the same time was kept open; (iii) the 200 compulsory redundancies did not happen, instead 100 volunteers signed up for redundancy but these redundancies happened over eighteen months not six months; (iv) delays in closing the third line and in making staff redundant allowed the engine room managers to demonstrate that the Dutch site had its own difficulties which had been masked by its projected production figures and, in consequence, Burnsland secured £9m investment into its remaining lines; (v) the two ‘unannounced’ production lines privately ear-marked for closure were reprieved indefinitely; (vi) the Chemco site manager returned to America and then retired early not long after the research period.

In terms of HRM practices, this paper next focuses on redundancy practices in relation to the Burnsland story broadly outlined above. We use ANT as a filter to view 
these redundancy practices in situ and in answer to Watson's (2004, p.447) call we consider (i) how the redundancy policy came into being, (ii) how this policy was interpreted by a noncanonical management community of practice which was able to operate invisibly whilst simultaneously operating as an official (canonical)

community and how the redundancy practice was employed in shaping strategy and (iii) shedding light on politics between managers in the practice of HR.

\section{Redundancy practices - canonical and non-canonical}

After the \$1bn acquisition, Chemco possessed several holdings in Europe (Burnsland, Holland, Luxembourg). Starting in February (year 1) a series of meetings were held with representatives of all the sites across Europe and America to discuss the initial rationalisation of production. Heath Hall (Burnsland's Production Manager) argued vehemently at these meetings that the site in Holland was using projected output figures whereas he was using actual output figures and the site in Holland had never achieved such output levels in the past despite having made similar promises to HCI.

On $23^{\text {rd }}$ March (year 1) it was announced that Ryan Cairn was to be the new Site Manager at Burnsland. The general sentiment of various Burnsland middle managers was positive - e.g. one middle manager said he was 'a good listener' and another middle manager said Ryan Cairn 'had expressed the view that he was impressed by the Site and the people.'

However, after Heath Hall the Production Manager's vehement arguments at the series of international meetings, Ryan Cairn, called his first senior managers meeting ( $29^{\text {th }}$ April, year one) and began by announcing that Heath Hall would be 
moved to an as yet unidentified role elsewhere following a short project role at Burnsland. The first that Heath Hall knew of this was then and there: in public in front of his peers during this first senior managers meeting. This caused considerable anger amongst the management team, both at the decision and the way it had been announced. For example, Andy Dalton was closely interrogated the following morning ( $30^{\text {th }}$ April, year one) by Ian Eastriggs (Operations Manager) and Kirsty Powfoot (Finance Manager) until Ian was satisfied that Andy did not know about the decision. However, as he was new to Burnsland the other managers wanted to be reassured that he did not know. When Ryan Cairn briefly returned to America (5 May year one) his secretary sent out an e-mail to inform Burnsland employees of the decision. Andy Dalton was 'wondering how the hell could he [Ryan Cairn] do this when Heath Hall had ...no discussion of why or what next'. A few months later, Heath Hall handed in his notice and resigned from Chemco.

It was after these meetings on the initial rationalisation of production that Chemco senior management in the US announced (April, year 1) they would close three out of the nine production lines at Burnsland immediately with a further 2 lines (known only by directors and senior/middle managers) earmarked for closure at a later stage.

Accordingly, Ryan Cairn (Site Manager) asked Ian Eastriggs (Operations Manager) and Andy Dalton (HR Manager) to make a series of redundancies within a very tight timetable (90 days), thus saving money, and to prepare three lines for closure. Ryan Cairn reassured Ian Eastriggs that his own future was safe at Burnsland and Andy Dalton was told by several senior managers in Chemco that he would have a 'promising future' in HR with them. In these ways, the Site Manager and his 
colleagues sought to enrol the Operations Manager and the HR Manager into the Chemco post-acquisition strategy, offering them career rewards in return for loyalty and the achievement of line closures and rapid redundancies.

Callon (1986) describes the process of 'enrolment' in terms of persuasion, threat and inducements and through these processes the new site manager sought to enlist both the Operations and HR managers into his own senior management community of practice which did things in the Chemco way, rather than the HCI way. This incident shows that, the incoming senior Chemco managers did not simply assume Burnsland managers would comply with their post-acquisition strategy. Rather they set out to cut deals with key individual Burnsland managers, protecting them in the hope of gaining their loyalty. This attempt at a transactional form of individual enrolment was only successful on the surface. It shows that the canonical Chemco community of management practice acted in manipulative and conniving ways, to achieve it's strategy; attempting to bribe both the Operations and HR managers with job security and promotion if they would speed up the process of closing production lines and making hard redundancies, thus betraying their colleagues and, potentially, due procedure. If successful, this manoeuvre would result in two new recruits into the canonical Chemco CoP of senior management.

This illustrates how the redundancy and line closure strategy was shaped in practice by the incoming Chemco top team and some of the politics between managers which recognised both canonical and non-canonical loyalties as well as business and interactional practices. And these subtleties of mobilising HR practices would be almost impossible to capture without a method such as self-ethnography, which capitalises on a manager acting as a researcher of their own context. 
On the $7^{\text {th }}$ July (year 1) Andy Dalton met with middle managers at Burnsland about redeployment. Dalton told them that 'the Engine Room would be restarted'. The phrase ‘Engine Room' had been used some years before in HCI when managing a voluntary redundancy scheme. In recollecting and re-using this phrase, Dalton invoked the collective memory of the group as all the managers present (with the exception of Dalton) had used this process to manage Burnsland redundancies a few years earlier. Similarly, Orr (1996) demonstrated how communities develop and maintain collective memory.

Andy Dalton suggested that 'HCI severance procedures could be used to manage things'. These procedures had evolved to resolve a specific dispute elsewhere in HCI and had become a collective memory across HCI sites. As Cook and Yanow (1993, p.443) in their study of a CoP of flute makers argued, knowledge may be learned collectively over time and not lost as a result of staff turnover. This suggests that such learning continues beyond the working life of current community employees, in a process very similar to the one described above at Burnsland. Thus, Burnsland and HCI old-timers could infer from Andy Dalton's cryptic comments that the Engine Room process using 'HCI severance procedures' would be voluntary and could be used to delay redundancies and production line closures. Picking up on this cryptic inference, in reply, one middle manager said: 'I’m glad that Ryan Cairn is away in the States', a remark, which made transparent to everyone that what was being agreed here, behind Cairn’s back was a way of slowing down the redundancy strategy whilst appearing to progress it by due procedure. This view was echoed by negative comments made throughout the meeting as participants: (a) distanced themselves from the Chemco way of managing redundancy and (b) began to see that there was an alternative - the old HCI way, invoked by Andy Dalton. No manager had 
publicly stated a collective desire to conspire against Chemco’s post-acquisition closure and redundancy strategy but they had all begun to see and pursue an alternative strategy, of voluntary redundancies, warranted by their collective recollection and revivification of an old HCI way of conducting redundancies.

In our account the concepts of COPT and ANT enable us to analyse how HR policies come into being and are employed in situ shaping strategy-in-practice. A managerial CoP (the Engine room) was reinvented from collective recollections and memory (cf. Orr 1996; Cook and Yanow 1993). By reinvoking HCI precedents, the CoP put fresh life and meaning into old HR policies and practices. Old agreements, as inscription devices, were mobilised into a network of actants and actors. All these interactions, in the Site Manager's absence, served to generate an alternative strategy to resist the redundancy programme. However, this alternative strategy could not be delivered without the enrolment of powerful others (unions, Chemco managers, politician, media) who would also invoke the Engine Room agenda. Ultimately this wider actor heterogeneous network of Engine room managers, HR practices and texts, and powerful others could then be mobilised to stop the Chemco way of managing redundancy and to counter-enrol Ryan Cairn and Chemco senior management into this non-canonical plan, without their conscious knowledge in some cases.

The Operations Manager and HR Manager, then called an official 'Engine Room' meeting of all the middle managers, representing every department at Burnsland. For former HCI staff with long memories the public use of the term 'Engine Room' recalled a strategy at odds with the Chemco strategy and this irony was clear to the HCI managers but not to their new Chemco superiors. Effectively the same people would participate in both the canonical Engine Room (apparently making redundancies fast) and the noncanonical Engine Room (making voluntary 
redundancies as slowly as possible); their HR practices would switch depending on who was present. When the Site Manager was present and their activities visible to him, they would act as if they were driving the redundancies forward as efficiently as possible, but when he was absent they would act to slow it down as much as possible. Neither the Operations Manager nor the HR Manager had any intention of closing the production lines in line with Chemco strategic timescales or making compulsory redundancies although officially that was precisely what the engine room meetings were for. For example, Ian Eastriggs (Operations Manager), Heath Hall (who was still Production Manager at this point) and Andy Dalton (HR Manager) had an impromptu meeting (18 June year 1) in Heath Hall's office to clarify headcount numbers and agree the overhead slides for the first public redundancy announcement planned for $22^{\text {nd }}$ June, year 1 . The three managers agreed to present the minimum amount of information in order to retain, as Ian Eastriggs put it, 'wiggle room for manoeuvre.' The next day, on the 19 June (year 1) Andy Dalton presented the agreed minimal information to all the middle managers at a pre-announcement meeting, to brief them before the public announcement of the redundancies planned on $22^{\text {nd }}$ June. Ryan Cairn interrupted throughout the briefing; this was seen as an attempt to appear in control of events by engine room members present who shared this interpretation of his behaviours through eyebrow raising from Ian Eastriggs and occasional grins from Kirsty Powfoot (Finance Manager). These clandestine nonverbal interactions enabled the engine room colleagues to maintain an ironic stance towards the public story at the very point it 'went public.'

The process, as Andy and Ryan explained it, was for each senior manager to allocate specific middle managers to communicate with specific affected employees. Dalton told the middle managers: 
'Now I want you to go through the list of names, there are five copies which I want back at the end, note down your actions separately. The best way to do this is to gather round your respective senior managers...We are not here to debate or discuss names'.

Ryan Cairn moved between groups as he was not assigned a group...he said 'Hey I haven't seen the list, this is the first time I've seen it.' At the time he was looking over Ian Eastriggs' shoulder and Ian nonchalantly turned the page from one department list to another so as to hide some contentious data. Thus Ryan Cairn was denied access to the data.

Although Ryan Cairn had a standing invitation to participate in the engine room meetings, generally he did not, until he began to worry that the promised redundancies were not happening fast enough. When he did attend, it was typically to hold the members to account and managers told stories of 'progress' towards the redundancy targets and at the end of the meeting one manager would engage Ryan Cairns in conversation while the meeting itself would reconvene in another office and continue seeking ways of delaying and stalling the official strategy. For example, in one meeting (15 June year 1) Ryan Cairn said: 'I feel nervous being left out of the detail, I'm not used to this but it sounds like you are confident'. Andy Dalton (HR Manager) said 'yes, I’ve done this before.' Dalton then explained how he had single handedly managed the process of compiling the names of all employees in Europe to transfer from HCI to Chemco. Ryan Cairn said 'I am a lot more confident now you've gotten a hold of this’. Everything Andy told Ryan had been true and had the effect of reassuring Ryan he was pulling in the same direction even though he was not. It is not the case that managers are simply in one $\mathrm{CoP}$ at a time, but it is the case that they can 
be in one CoP in public and another in private and engaged in different practices simultaneously pulling in opposing directions. Also the process of 'passing' as members of different communities of practice actually in conflict was a regular feature of former HCI managers’ practice. It also took Andy Dalton several attempts to reassure Ryan Cairn that the detail he was anxious about was being 'looked after', without demonstrating that this was not in the way Ryan might infer.

On the occasions when the Site Manager was not in attendance the engine room colleagues focused on how to juggle people from one area to another to ensure output was maintained on threatened production lines whilst achieving just enough volunteers for redundancy to keep Ryan Cairn and the Directors at bay.

Through Andy Dalton's assurances to Ryan Cairn that he had (a) handled redundancies previously (factually true) and (b) that they should use the same process now (legally arguable), the former HCI redundancy handling agreement with the unions was recognised and inherited by Chemco. The agreement, literally a text (or an inscription device in Foucault's language) called for redundancies to be conducted on a voluntary basis and for all other alternatives to be fully explored before compulsory redundancies were carried out. This agreement had been developed and used twenty years previously to resolve a specific industrial relations issue and had been respected over the subsequent twenty years in HCI, becoming custom and practice.

At several meetings of senior managers at Burnsland over the next 6 months, the Site Manager urged that: 'at times like this we need to be good foot soldiers and trust our leadership. They know what they are doing'. Open debate amongst the team was therefore discouraged and Burnsland managers became guarded in their 
conversations at other sites and at company-wide meetings. In another example, Ryan Cairn said 'I need to ask you to make sure we are not seen to be blocking things or obstructive' (15 ${ }^{\text {th }}$ January, year two). He meant that he did not want Chemco top management in the US to see Burnsland staff blocking things and being obstructive, and indeed the engine room shared this concern.

In a similar exhortation, on $26^{\text {th }}$ January (year two) the evening before another off-site private company meeting of European senior managers and Chemco directors, Ryan Cairn said to Andy Dalton and Patrick Port (Burnsland Research Manager) that: 'we as Burnsland need to be seen to be delivering and ...we should not rock the boat'. Ian Eastriggs (Operations Manager) then joined the conversation and Ryan repeated his message. Once again, in this incident we can see that both Ryan and the engine room colleagues had similar concerns about how they would be seen by the people above them. He and they both needed to be seen as making due progress. His urgings were another attempt to enrol and mobilise the former HCI managers into the process of convincing his superiors of the efficiency of his and their management actions. He therefore shared non-canonical practices with them, i.e. practices of trying to look good in the eyes of top management, without the latter realizing the real state of play. He wished his superiors to think he was making more progress than he was, just as the engine room, unbeknown to him, wished him to think that they were making more progress than they were.

At several off-site pan-European senior management meetings, the Burnsland managers agreed privately amongst themselves that they would deliberately remain silent in meetings, as the risks to their own jobs was obvious. Thus, whenever their actions were visible to their seniors, these managers now actively conformed to the appearance of being 'good foot soldiers,' exhibiting the behaviour required of them to 
remain as managers within the Chemco network. For example, on the day before another off-site meeting on $26^{\text {th }}$ January (year two), to discuss production line closures with Directors and Site Managers from Europe, it was agreed prior to the meeting that the Burnsland managers would keep quiet.

\section{Discussion}

Watson (2004) called for more critical qualitative accounts of HRM. In particular he urged researchers to consider (i) how policies come into being, (ii) how strategy is shaped and (iii) politics between managers. In the Burnsland story the 'redundancy handling agreement' came into being many years before our account begins as a device to settle an industrial dispute. Many subsequent HCI disputes had been settled by quickly working through the terms of that agreement and then making compulsory redundancies. However, this HCI history was recounted in a more selective way at Burnsland, so that the agreement could be used as an inscription device by the engine room to shape (i.e. alter) the intended strategy of compulsory redundancies and line closures. While this kind of political struggle between managers has been reported elsewhere (Dalton 1959; Watson 1994) our study exemplifies some of the power relations in HR work (see also, Vickers 2005).

From ANT we specifically focus on the ideas of enrolment and translation and from communities of practice theory we focus on non-canonical communities and storytelling. In our discussion above we are able to see how informal HR practices of storytelling are used to gain commitment and buy-in to non-canonical CoP as one form of actor-network. This is seen in Andy Dalton's initial invocation of the Engine Room and the many subsequent invocations by other Engine Room managers, verbal 
and non-verbal, which we describe. Storytelling practices were also used in other ways, to counter suspicions, for instance, when Ryan Cairn queried Andy’s loyalty to Chemco senior management, Andy told a story of his prior experience in handling headcount operations, Europe-wide.

Standing back from these local interactional incidents within our data, the process of enrolment is at the discursive core of the normative agenda - especially in best fit models - where certain employee 'needs are met' in order to 'gain commitment' or 'empowerment'. Enrolment practices are simply presumed (a) to be legitimate and (b) to work in unitary conceptions of HRM and management generally. But our data, informed by ANT and COPT, show that this is not a safe assumption. Interactions of enrolment and counter-enrolment enable some networks to stabilise or be simplified and 'black-boxed' and cause others to collapse. For example the site manager attempted to use some HR practices (e.g. career advancement and job security) to encourage or enforce conformity and compliance. Although on the surface these seemed to work, they failed in practice and the processes of counter-enrolment continued unabated. Even the Site Manager's actions were unwittingly enrolled into the non-canonical Engine Room network operating against Chemco’s strategy.

The ANT idea of translation enables us to highlight how HR practices involve micro-political negotiating which translates and converts many different groups of managers' competing interests (the politics between managers) into a public course of action which most managers and others seem to work towards (how strategy is shaped in practice). As Law (1992, pp. 385-6) puts it, it is by analysing 'local processes of patterning, social orchestration, ordering and resistance' that we are able to understand how HR practices are conducted in situ and how they are engaged in ordering and resistance. 
Therefore public micro-practices of a textual interpretation - of the 'redundancy handling agreement' - were used to generate a new inequality in the power relations between Chemco and the Engine Room managers, in the direction of the latter. Power is not seen as a possession or thing but as an emergent attribute of the functioning of networks, not diffused from above nor centrally, but arising in the interactions between people and people, people and texts. The invisible nature of the noncanonical Engine Room allowed its members to coordinate actions in ways that produced the power to derail the canonical Chemco management's strategy. Networks attempt to stabilise themselves through the social production and circulation of texts that guide, constrain and shape strategic choices (how policies come into being and how strategy is shaped).

As in Orr (1990, 1996), by focusing on storytelling practices, those of the Engine Room managers including the HR manager, we have been able to demonstrate how a noncanonical community is able to shape strategy and interpret existing policies and practices to its own political ends. In methodological terms, this focus on storytelling is one where the traditions of ANT, COPT and ethnography meet. The work of storytelling is where ANT crosses the resources of ethnomethodology with semiotics, especially Garfinkel’s ‘key notion of ‘accountability’’ (Latour 2005, pp 122). ANT stems from the Greimasian idea of 'narrative trajectory' (Czarniawska 2004, 2005) whereby an actor may change roles and become some object for another actor's action. Such a narrative approach can be used to show 'how macropictures are drawn, [and] micro studies problematize the taken for granted' (Czarniawska 1998, p. 49). From Orr’s $(1990,1996)$ communities of practice-based ethnography of photocopier technicians at work we see how technicians tell each other war stories as a feature of their work. These stories are not just about the work but are the work, or 
at least are part of their work, because they are part of how they diagnose problems and help to preserve the knowledge acquired within the community of practice.

In a similar way, storytelling is not only a methodological focus we have employed but it is also a pervasive part of everyday Burnsland practice. In our study of HR work in the context of organisational change, there are differences from Orr's technicians which matter. Unlike the technicians who largely worked on their own on a client's premises but later talked about their work with their colleague so that they too would know how to fix a particular machine if called out to do so one day, a good deal of this orchestration work involved planning how to tell a story on a future occasion, how to configure the overhead projector slides, how to lay out the background to the events, how to depict plans for how middle and senior managers should act.

Each time the story-so-far was told to an audience it served to remind them of relevant facts leading to the present point and it often primed them for how they should act next. In this way, story-telling functioned for the group as it did for Orr's technicians, it re-invoked a diagnosis and it helped them to apply their knowledge of the past to their present, hence preserving their knowledge further. The story-telling set the scene and was followed by enacting which played out the parts assigned to the audience relayed by the story. Sometimes, the HR manager's version of events might be challenged, or when the Site Manager expressed anxiety about not knowing the relevant detail. On these occasions, fresh and further stories were told in order to maintain enrolments and counter-enrolments in each others' networks.

However, within Burnsland were many different contexts; a feature of management work is that it does not all happen in one meeting or one type of meeting. It is distributed across many meetings, many offices, with different 
personnel on hand with differing membership loyalties and commitments on differing occasions. What we found was that in the work of collaborative interaction, the HR manager and his close allies (including the Operations Manager and sometimes the Site Manager himself) would often come from one context into the engine room and would relay the story so far or the latest bit of news. In doing so, they set the scene for the actions that followed. For instance, when Andy Dalton presented the redundancy process to the assembled middle managers ahead of a public announcement, his way of presenting what they should do next relied upon, invoked and triggered collective recollections of ways of acting. These were in accordance to redundancy handling agreements, invisible to Ryan Cairn. The actions that followed were actions in accordance with a story recollected but not publicly available. The story prompted the action that followed by labelling the situation as the sort of occasion it was by recalling the engine room of HCI's past. As Orr tells us: 'stories that work well for members of a culture may seem remarkably cryptic and elliptical to outsiders' (1996, pp 141) and the middle managers knew how to act based on Andy's elliptical references to their collective history. At the same time when Ryan Cairn felt the lack of the necessary detail to follow the process, Andy could then tell a further story of his past which did not supply the detail Ryan was missing but did provide the reassurance Ryan wanted. When Andy and Ryan both reported to the middle managers the story-so-far, members of the engine room staff, could recognise two alternative accounts, one told by and visible to Ryan and another told by and visible to everyone except Ryan. Storytelling in these varied contexts was rarely simply verbal, but also frequently relied upon prior written agreements and lists and documents or overhead slides applying the past agreement to the present. In these ways texts from the past and texts crafted in the present relayed the story and materially embodied its 
implications for the immediate future. There were cryptic expressions embodied in raised eyebrows, knowing grins and the quick turn of a page to hide information. And in this whole process the very act of ethnographic writing, preserves some of the main lineaments of the story, as observed by one of the participating actors.

After our period of research many of the senior managers at Burnsland left Chemco and there was a further redundancy exercise - this time it was, officially, a voluntary process and the Engine Room was re-established by the middle managers (now newly promoted to senior roles) and this time they bypassed the new HR manager (the site manager’s appointee). As Orr (1996) has noted, part of the reason for story telling and diagnosis is to preserve knowledge for the wider CoP. This we would argue can also be achieved over a period of time by different actors.

\section{Conclusion}

We suggest that practice-based studies of HR, and self-ethnographic studies of HR-inpractice add to extant literature and encourage greater dialogue between HR practitioners and their critics. Hopefully it will also encourage a wider debate on the politics of HRM and management at large as a professional practice which deals with tensions and ambivalences within management practices at large. In particular future research into HRM needs to recognise and embrace the micro-political aspect of HR work and seek to illuminate it. The Burnsland case not only demonstrates that HR practice is a highly political management process but also shows how, in the case discussed, it involves complex micro-political and interactional calculations and sensitive assessments of the value of different human contributions to the overall value-chain of a firm (e.g. Keenoy 1999; Watson 1994). This is in stark contrast with approaches which downplay the political aspect of HR. We have been able to describe 
and critically analyse the way networks were created, extended, maintained, undermined and overturned within one organization. This allowed us to show inequalities of power both: (a) being generated, through interactions which built new networks, and (b) being used to undermine established network-effects in a locally situated context.

We do not claim that our particular study or the approach we have taken to it results in a generalizable model but we have demonstrated what potential there is in moving beyond many of the normative studies of core HR practices.

David Vickers is a Senior Lecturer in Lancashire Business School at the University of Central Lancashire in Preston, UK.

Steve Fox is Professor of Social and Management Learning at Lancaster University.

Acknowledgements: The authors would like to thank Elaine Swan from Lancaster University, the anonymous peer reviewers and the editors for helpful suggestions regarding earlier drafts. 


\section{References}

Alvesson, M., (2003), 'Methodology for close-up studies. Struggling with closeness and closure', Higher Education, 46, 167-193.

Alvesson, M., Hardy, C., and Harley, B. (2008) 'Reflecting on Reflexivity: Reflexive Textual Practices in Organization and Management Theory', Journal of Management Studies, 45, 3, 480-501.

Brown, J.S. and Duguid, P., (1991), 'Organizational Learning and Communities of Practice - Toward a Unified View of Working, Learning and Innovation', Organization Science, 2, 1, 40-57, February.

Brown, J.S. and Duguid, P. (2001), 'Knowledge and Organization: a social-practice perspective’, Organization Science, 12, 2, 198-213.

Burrell, G and Morgan, G. (1979) Sociological Paradigms and Organizational Analysis. London, Heinemann Educational Books.

Callon, M. (1986), 'Some elements of a Sociology of Translation: Domestication of the Scallops and the Fishermen of Saint Brieuc Bay', in Power, Action and Belief, ed. J. Law, London: Routledge \& Kegan Paul, 196-233.

Callon, M. and Law, J. (1982), 'On Interests and their Transformation: Enrolment and Counter-Enrolment’, Social Studies of Science, 12, 615-25.

Cook, S. D. N., Yanow, D., (1993) 'Culture and Organizational Learning', Journal of Management Inquiry, 2, 373-390.

Czarniawska, B. (1998), 'a Narrative Approach to Organization Studies', Qualitative Research Methods Series, 43, London, Sage.

Czarniawska, B. (2004), 'On Time, Space, and Action Nets’, Organization, 11, 6, 773-791.

Czarniawska, B. and Hernes, T. (2005), eds., Actor-Network Theory and Organizing, Copenhagen, Liber.

Dalton, M. (1959), Men Who Manage: Fusion of Feeling and Theory in Administration, New York: Wiley.

Ellis, C. and Bochner, A. (2000), 'Auto-ethnography, personal narrative, reflexivity', in Handbook of Qualitative Research, eds., N. Denzin and Y. Lincoln, Thousand Oaks: Sage.

Foucault, M (1979) Discipline and Punish, London: Penguin.

Foucault, M (1991) 'What is an Author?' in Foucault Reader, ed. P. Rabinow, London: Penguin, 101-120, 
Fox, A. (1974) Beyond Contract: Work, Power and Trust Relations, London, Faber and Faber.

Fox, S. (1989), 'the Panoptican: from Bentham's Obsession to the Revolution in Management Learning’, Human Relations, 42, 8, 717-39.

Fox, S. (2000), 'Communities of Practice, Foucault and Actor-Network Theory', Journal of Management Studies, 37, 6, 854-67.

Fox, S. (2005), 'an Actor-Network Critique of Community in Higher Education: Implications for Networked Learning’. Studies in Higher Education, 30, 1, 95110.

Fox, S. (2006), ‘ Inquiries of Every Imaginable Kind: Ethnomethodology, Practical Action and the New Socially Situated Learning Theory', Sociological Review, 54, 3, 426-45.

Garfinkel, H. (1967), Studies in Ethnomethodology, New Jersey: Prentice Hall.

Gherardi, S. (2009), 'Introduction: the Critical Power of the 'Practice lens', Management Learning, 40, 2, 115-28.

Hammersley, M. and Atkinson, P. (1983), Ethnography: Principles in Practice. London, Tavistock.

Hughes, J., Jewson, N., and Unwin, L. (2007), Communities of Practice: Critical Perspectives, London: Routledge.

Hutchins, E. (1991), 'Organizing Work by Adaptation’. Organization Science, 2, 1, 14-39.

Hutchins, E. (1995), Cognition in the Wild, Massachusetts: MIT Press.

Jackall, R. (1988) Moral Mazes: The World of the Corporate Manager. New York: Oxford University Press.

Jewson, N. (2007), 'Cultivating Network Analysis: Rethinking the Concept of 'Community' Within 'Communities of Practice', in Communities of Practice: Critical Perspectives, eds., J. Hughes, N. Jewson, and L. Unwin, London: Routledge.

Keenoy, T. (1999), 'HRM as Hologram: A Polemic', Journal of Management Studies, 36, 1, 1-23, January.

Latour, B. (1986), 'The Powers of Association', in Power, Action and Belief, ed. J. Law, London, Routledge, 264-80.

Latour, B. (1987), Science in Action: How to Follow Scientists and Engineers through Society, Cambridge, Mass.: Harvard University Press. 
Latour, B./ Johnson. J (1988) 'Mixing Humans and Nonhumans Together: The Sociology of a Door Closer’. Social Problems 35, 3, 298-310.

Latour, B. (2007), Reassembling the Social- An Introduction to Actor-NetworkTheory, Oxford: Oxford University Press.

Lave, J and E, Wenger (1991) Situated Learning: Legitimate Peripheral Participation. Cambridge: Cambridge University Press.

Law, J. (1986), 'On Power and Its Tactics: a View from the Sociology of Science.' The Sociological Review 34, 1-38.

Law, J. (1991), ‘Power, Discretion and Strategy', in Sociology of Monsters, ed. J. Law, London: Routledge, 165-91.

Law, J. (1992) 'Notes on the Theory of the Actor-Network: Ordering, Strategy and Heterogeneity’, Systems Practice 5, 4, 379 -393.

Law, J. and Hassard, J. (1999), eds., Actor Network Theory and After, Oxford: Blackwell.

Luff, P., Hindmarsh, J., and Heath, C., (2000), eds., Workplace Studies, Cambridge: Cambridge University Press.

Mintzberg, H. and Walters, J.A., (1985) 'Of Strategies, Deliberate and Emergent', Strategic Management Journal, 6: 257-72.

Moser, I and Law, J (1999), 'Good Passages, Bad Passages’, Actor Network Theory and After, eds. J. Law. and J. Hassard, Oxford, Blackwell, 196-219.

Orr, J. E. (1990), 'Sharing Knowledge, Celebrating Identity: War Stories and Community Memory in a Service Culture', in Collective Remembering: Memory in Society, eds. D.S. Middleton, and D. Edwards, Beverley Hills, CA, Sage, 169-89.

Orr, J.E. (1996), Talking About Machines: An Ethnography of a Modern Job. New York, Cornell University Press.

Purcell, J. (1999), 'Best practice and Best fit: Chimera or cul-de-sac', Human Resource Management Journal, 3, 9, 26-41.

Singleton, V and Michael, M (1993) 'Actor Networks and Ambivalence: General Practitioners in the UK Cervical Screening Programme'. Social Studies of Science 23, 227-264.

Townley, B (1993a), 'Foucault, Power/Knowledge, and its Relevance for Human Resource Management', Academy of Management Review, 18, 3, 518-545.

Townley, B (1993b), 'Performance Appraisal and the Emergence of Management', Journal of Management Studies, 30, 2, 27-44. 
Townley, B (1998), 'Beyond Good and Evil: Death and Division in the Management of Human Resources' in Foucault, Management and Organization Theory, eds. A. McKinlay and K. Starkey, London: Sage, 191-210.

Vickers, D. A. (2005), A Study of Burnsland: Strategic Organisational Change and Power during an Acquisition, Doctoral thesis, Lancaster University, Department of Management Learning and Leadership.

Vickers, D and Fox, S (2005) 'Powers in a Factory', in Actor-Network Theory and Organising, eds. B, Czarniawska and T. Hernes, T Copenhagen: Liber.

Watson, T. J. (1994), In Search of Management: Culture, Chaos and Control in Managerial Work, London: International Thomson Business Press.

Watson, T. J. (2004), 'HRM and Critical Social Science Analysis', Journal of Management Studies, 41, 3, 447-467, May.

Wenger, E (1998) Communities of Practice: Learning, Meaning, and Identity. Cambridge: Cambridge University Press.

Whittington, R. (1996), ‘Strategy as practice’ Long Range Planning, Oct., 731-5. 